\title{
Productive Potential, Market Access and Smallholder Livestock Production: Evidence from southern Zambia
}

\author{
Gelson Tembo ${ }^{1, *}$, Fusya Y. Goma ${ }^{2}$, Alice Tembo ${ }^{3}$ \& Stephen Kabwe ${ }^{4}$ \\ ${ }^{1}$ Department of Agricultural Economics, University of Zambia, P.O. Box 32379, Lusaka, \\ Zambia \\ ${ }^{2}$ Veterinary Department, Ministry of Agriculture and Livestock, Lusaka, Zambia \\ ${ }^{3}$ Ministry of Mines, Energy and Water Development, Luanshya, Zambia \\ ${ }^{4}$ Indaba Agricultural Policy Research Institute, Lusaka, Zambia \\ *Corresponding author: Department of Agricultural Economics, University of Zambia, P.O. \\ Box 32379, Lusaka, Zambia. E-mail: tembogel@gmail.com
}

Received: March 6, 2014 Accepted: April 20, 2014 Published: June 5, 2014

doi:10.5296/rae.v6i2.5774 URL: http://dx.doi.org/10.5296/rae.v6i2.5774

\begin{abstract}
This paper uses household data collected from livestock-rearing communities in 3 districts in Southern Province of Zambia and corner-solution econometric models to measure the effect of productive potential and market access on livestock production. We also test for the existence of heterogeneous effects across agro-ecological regions, livestock species and poverty levels. To the best of our knowledge, no study has done this before. The findings identify the need for policies and interventions that are aimed at strengthening livestock-based livelihood systems to be responsive to not only the target groups but also productive potential and market access characteristics of the communities in which they live. The livestock systems inherent in the various districts and communities also need to be explicitly taken into account.
\end{abstract}

Keywords: Tobit, tropical livestock units, cattle, goats, poultry, Southern Province, Zambia 


\section{Introduction}

Zambia is a landlocked country in sub-Saharan Africa with a total land mass of 751,000 square kilometers and a total population of 13 million as of the 2010 national census (CSO 2010). Livestock keeping is an important economic venture with 31.6 percent of the households keeping some type of livestock. More than 93.6 percent of all the livestock are reared by rural households (CSO, 2004). At the time of the study the national herd consisted of about 2.5 million cattle, 956,304 goats, 101,191 sheep, and 538,393 pigs (DVLD 2007). Of the 10 provinces, Eastern, Southern and Western Provinces are the leading producers of cattle (Lubungu \& Mukuka 2012).

There are two major livestock production systems in Zambia: i) the traditional sub-sector based on open communal pastures, and ii) the commercial sub-sector with fenced pastures (Aregheore, 2006). For traditional farmers, livestock perform important economic and social functions, including as a form of savings/assets, an insurance to mitigate against risks and shocks, a source of manure for crop production, a provider of animal draught power (ADP), a means for paying bride prices, and as a symbol of status and wealth (Randolph et al. 2007; Stroebel 2008; Chilonda et al 2000; Mandleni and Anim 2012).

Traditional livestock farmers also play a pivotal role in the supply of livestock to the livestock industry especially in the beef sub-sector. However, this category of farmers is characterized by a number of constraints, major ones being low productivity and limited access to livestock markets (Aregheore, 2006; Negassa 2008). Low productivity is manifested in low production and reproduction parameters which result in reduced meat yields and low livestock numbers (Simbaya 2002), often exacerbated by insufficient and low quality of feed, diseases, poor animal husbandry and inadequate extension services (Daka, 2002; Simbaya 2002).

While livestock production is itself considered enough indication that the household is well off (Ali and Khan 2013), investment in improved market access is regarded as a sure means to accelerate rural poverty reduction (Chapoto et al. 2011). Low market access is often blamed on limited numbers of livestock owned, long distances to main roads, impassability of roads, and crop commercialization (Lubungu et al. 2012, Negassa 2008). Makhura (2001) contends that market participation is higher for smaller livestock, which tend to be reared by female farmers and mainly for livelihood purposes rather than for social status.

Conventional wisdom contends that productive potential and market access are important ingredients for the development of the smallholder livestock sector. However, there is virtually no empirical evidence on the farmers' responsiveness to both these conditions. Do proximity to markets and abattoirs and/or good roads, for example, motivate farmers to increase their livestock production? Very few studies have looked at the effect of community productive potential and market access on livestock ownership (Ali and Khan 2013 and Rooyen and Tui 2009).

This paper uses household data collected from livestock rearing communities in 3 districts in Southern Province of Zambia to measure the effect of the communities' productive potential 
and market access on livestock production. We also test for the existence of heterogeneous effects across agro-ecological regions, livestock species and poverty status of the household. Unlike most prior studies that use narrow measures of welfare like income or expenditure (Deshingkar et al., 2008, Greeley 1994), we use a more comprehensive participatory wealth ranking exercise to classify the households into wealth strata. To the best of our knowledge, no study has looked at all these issues so comprehensively within a mixed-methods framework.

Our study contributes to the literature in two other important respects. First, the study departs from the usual narrow representation of market access (distance to roads, markets, etc) (Ali and Khan 2013; Rooyen and Tui 2009) and uses knowledgeable key informants to assign market access statuses to study communities. The key informants use not only their knowledge of the distances but also several other factors, including, but not limited to, the state of the roads, and the size and versatility of market opportunities in general. This is much more informative than just distances. Second, our study unravels the differential responsiveness associated with different types of livestock, agro-ecological regions and poverty levels. The findings from this study should help in the design and implementation of effective interventions that aim to strengthen livestock-based livelihood systems in developing country contexts.

\section{Materials and Methods}

\subsection{Data and Data Sources}

A mixed-methods survey methodology was used in the three study districts of Kazungula, Namwala and Sinazongwe. Southern Province has been experiencing frequent droughts and floods during much of the last few decades, often prompting food assistance to vulnerable populations. Of the country's ten provinces, Southern Province also stands out as one with the largest and most diversified smallholder livestock sub-sector in Zambia. Thus, lessons from that province could apply to a wide spectrum of circumstances throughout much of the developing world.

Sinazongwe is located in the valley and accounts for the highest population of goats in Southern Province. Kazungula and Namwala, located on the plateau, have large populations of cattle with Namwala having the largest population in the entire province. Each district is divided into veterinary camps which are the primary units for animal health provision, each manned by a veterinary assistant, who is the interface between the Veterinary Department and the farmers. 
Table 1. Stratification variables for communities and households

\begin{tabular}{|c|c|c|c|}
\hline $\begin{array}{l}\text { Stratifying } \\
\text { variable }\end{array}$ & Selection Method & Code & Code description \\
\hline \multirow{4}{*}{ 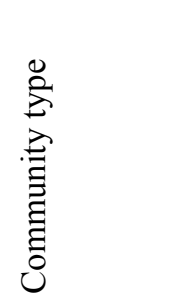 } & Purposively, with the help of & 1 & Low productive potential, low market access \\
\hline & district level key informants; & 2 & Low productive potential, high market access \\
\hline & most from the District Veterinary & 3 & High productive potential, low market access \\
\hline & Office (DVO) & 4 & High productive potential, high market access \\
\hline \multirow{3}{*}{ 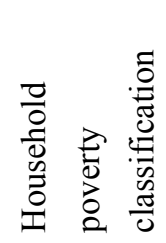 } & Determined collectively by the & 1 & Non-poor \\
\hline & community members during & 2 & Poor \\
\hline & $\begin{array}{l}\text { participatory wealth ranking } \\
\text { exercises }\end{array}$ & 3 & Extremely poor \\
\hline
\end{tabular}

Within each selected district and prior to primary data collection, all the veterinary camps or communities were classified into four distinct groups based on relative livestock productive potential (high or low) and market access (high or low) based on state of the road, availability of abattoirs, and/or availability of livestock markets (Table 1). The status of each veterinary camp with respect to these criteria was determined in consultation with knowledgeable key informants at the district veterinary office. One community was then randomly selected from each of the four community strata, making a total of 12 communities across the three districts.

In each selected community, a number of complementary quantitative and qualitative research techniques were used to collect the required data and information. The community participatory assessment process begun with a social mapping exercise to help understand the community's institutional, resource and asset context as well as to categorize the individual households into wealth strata based on their degree of vulnerability to poverty. The wealth ranking exercise was conducted collectively by all the community members involved in the participatory community mapping exercise. Through this process, each household in the community was assigned to one of three wealth strata - non-poor (NP), poor (P) and extremely poor (EP) (Table 1).

For operational purposes, a household was categorized as NP if it had enough to eat throughout the year, i.e. from harvest to harvest; as P if it normally had enough food to last from harvest up to Christmas but not between Christmas and the next harvest; and as EP if it had a longer period of food shortages, often experiencing severe food shortages even before Christmas. The allocation itself was done by the communities themselves through a participatory consultative process.

The wealth ranking process was facilitated by a small listing questionnaire, which enabled the data collectors to list all the households in the community and to assign the wealth strata to them. The listing form also asked a number of additional questions on the households' socio-economic conditions, including livestock and asset ownership. The filled-in listing 


\section{Macrothink

form also served as a community-level household sampling frame, from which households were randomly selected to participate in focus group discussions (FGDs) and in-depth interviews. This study uses only the community census data collected through the listing exercise. A total of 309 households were listed and interviewed across all the communities in the three districts.

\subsection{Analytical Framework}

The data from the listing exercise were entered and cleaned in the Statistical Package for Social Sciences (SPSS). The cleaned data were then analyzed for descriptive statistics using SPSS and Microsoft Excel. More advanced analyses, such as mean-difference statistical tests by one-way analysis of variance (ANOVA) and econometric estimation of the livestock ownership models, were performed in Stata.

We model livestock production as a function of a vector of household characteristics (h), wealth status of the household (w), and productive potential and market access associated with the community in which the household is located (c):

$$
y=f(\mathbf{x}),
$$

where $y$ is livestock owned per capita, and $\mathbf{x}=\{\mathbf{h}, c, w\}$. Equation (1) was estimated for all livestock species together, as well as for each of the major individual livestock specie (cattle, goats and poultry). The dependent variable, $y$, was measured as the number of heads for the individual livestock models, and as tropical livestock units (TLUs) for the models that combine all livestock species together. (Note 1)

We use the Chow test for model structural change to ascertain whether we are justified to estimate the three specie-specific models individually, as opposed to fitting one super-model in which inter-specie differences are captured by specie dummy variables. The results of the Chow test confirm that cattle, goats and poultry have structurally different production models; rejection the assertion that they should be modeled in one equation ( $\mathrm{F}$ statistic $=9.116$; p-value $<0.0001)$. 


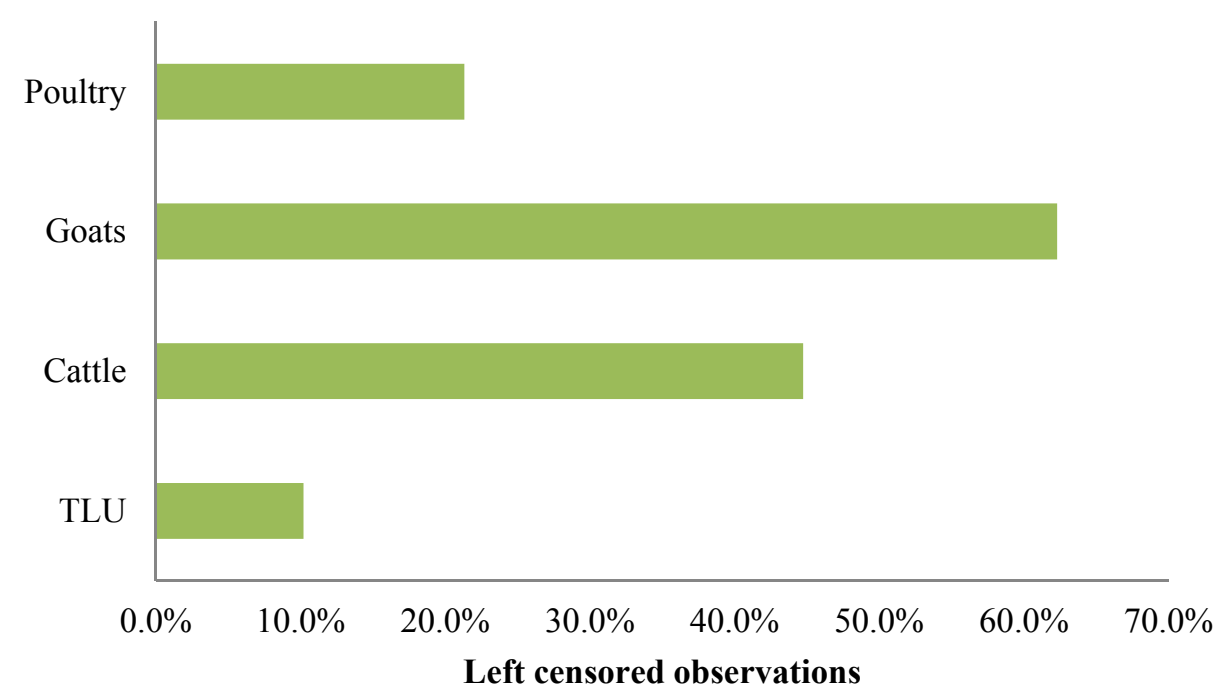

Figure 1. Proportions of households not producing livestock of various species

We noticed that, in each and every one of the cases considered, $y$ is heavily censored at zero, resulting in a corner-solution outcome (see Figure 1). Goats are the most censored with more than 62 percent of the households not rearing any; whereas, overall, only 10 percent keep no livestock at all. When the dependent variable is censored, ordinary least squares (OLS) would generate inconsistent parameter estimates (Gujarati, 2003; Wooldridge, 2009). Cragg's (1971) alternative to the traditional tobit is considered to be the ideal model as it allows the decision to enter into livestock production and the numbers of livestock reared to be modelled as two separate processes (Lin and Schmidt, 1984; Mulenga et al. 2014). Cragg's (1971) model is specified as:

Tier 1: $\operatorname{Pr}\left(D_{i}=1 \mid \mathbf{x}\right)=\mathbf{x} \gamma+\mu_{i}$

Tier 2: $y_{i}=\mathbf{x} \beta+\varepsilon_{i}$

where $D_{i}$ is a dummy variable equal to 1 if the household owns some livestock and zero otherwise, $\gamma$ and $\beta$ are vectors of parameters to be estimated, and $\mu_{i} \sim N\left(0, \sigma_{\mu}^{2}\right)$ and $\varepsilon_{i} \sim N\left(0, \sigma_{\varepsilon}^{2}\right)$ are random error terms that are assumed to be independent of each other. Under the assumption of independence, models (2) and (3) can be estimated separately as a probit and a truncated regression, respectively. However, in this study, this was not possible as equation (3) could not converge. Thus, we estimate the two tiers in a standard tobit framework but with the marginal effects for the two tiers computed and presented separately. The Tobit model, initially developed by Tobin (1958), is defined as 


$$
y_{i}= \begin{cases}y_{i}^{*} & \text { if } y_{i}^{*}>0 \\ 0 & \text { otherwise }\end{cases}
$$

where $y_{i}^{*}=\mathbf{x} \boldsymbol{\beta}+\mu_{i}$ is a latent variable, and $\mu_{i}$ is a normally distributed random error term with mean zero and constant variance $\sigma^{2}$ (Wooldridge 2009). In effect, the Tobit model is a combination of a probit (at the censoring point) and a linear regression model (when above the censoring point). The estimates of a Tobit model approach those of ordinary least squares (OLS) as the degree of censoring tends to zero, and are inconsistent if the error term is heteroskedastic.

We first estimate two tobit models for all livestock under the household's care with per capita tropical livestock units as the dependent variable, one where the latent equation is specified without interaction terms:

$$
y^{*}=\beta_{0}+\beta_{1} \mathbf{h}+\beta_{2} c+\beta_{3} w+\mu
$$

and one that includes interaction terms between community characteristics and household wealth strata:

$$
y^{*}=\lambda_{0}+\lambda_{1} \mathbf{h}+\lambda_{2} c+\lambda_{3} w+\lambda_{4}(c \times w)+\mu
$$

These models provided an overall picture, without differentiating across species. To understand inter-specie differences, we estimate the full model (with interactions) for each of the major livestock species - cattle, goats and poultry. In all these models, community type and wealth strata were represented as dummy variables. All the models were estimated with robust standard errors as a means to correct for heteroskedasticity, which was detected through the Breusch-Pagan test.

Following McDonald and Moffit (1980), we compute the marginal effects for the two tiers as:

$$
\frac{\partial E(y)}{\partial x_{j}}=\Phi(z) \frac{\partial E(y \mid y>0)}{\partial x_{j}}+E(y \mid y>0) \frac{\partial \Phi(z)}{\partial x_{j}}
$$

where $\Phi(z)$ is the standard normal cumulative distribution function evaluated at $z=\frac{\mathbf{x} \boldsymbol{\beta}}{\sigma}$, $E(y)$ is the unconditional expected value of $y$, and $E(y \mid y>0)$ is the expected value of $y$ given that $y$ is above zero. Equation (7) implies that the overall effect of a small change in an explanatory variable can be decomposed into: i) the change in numbers of livestock owned per capita by livestock producing households, weighted by the probability of adopting the practice; and ii) the change in the probability of rearing livestock, weighted by the expected 
number of livestock among owners.

\section{Results and Discussion}

\subsection{Household Socio-Economic Characteristics}

Table 2 presents and compares basic demographic and access characteristics, and asset and livestock ownership across the food security and district strata. As expected, households in hotspot districts have much less desirable attributes and indicators of wealth than their counterparts in the non hotspot district. For example, households in the non-hotspot district, on average, were 19 percent more likely to be male-headed, and had at least six times as many cattle, twice as many oxen, six times as many pigs, three times as many poultry, and more than twice as many ox-drawn implements as their counterparts in the two hotspot districts (Table 2).

Table 2. Basic household demographic characteristics and asset base across household food security and district strata

\begin{tabular}{|c|c|c|c|c|c|c|c|c|}
\hline \multirow[b]{2}{*}{ Variable } & \multicolumn{4}{|c|}{ Hot spot districts } & \multicolumn{4}{|c|}{ Non-hotspot district } \\
\hline & All & $\begin{array}{l}\text { Non- } \\
\text { poor }\end{array}$ & Poor & $\begin{array}{l}\text { Extremely } \\
\text { poor }\end{array}$ & All & $\begin{array}{l}\text { Non-p } \\
\text { oor } \\
\end{array}$ & Poor & $\begin{array}{l}\text { Extremely } \\
\text { poor }\end{array}$ \\
\hline \multirow{3}{*}{ Number of households } & (1) & $(2)$ & (3) & (4) & (5) & (6) & ( 7$)$ & $(8)$ \\
\hline & 213 & 69 & 69 & 74 & 96 & 25 & 33 & 38 \\
\hline & \multicolumn{8}{|c|}{----------------------- Proportion of households with ---------------------- } \\
\hline Male heads & 0.79 & 0.91 & 0.86 & $0.61 * * *$ & 0.94 & 1.00 & 0.94 & 0.89 \\
\hline Modern houses & 0.21 & 0.38 & 0.19 & $0.07 * * *$ & 0.19 & 0.54 & 0.12 & $0.03 * * *$ \\
\hline \multirow{2}{*}{ Membership to groups } & 0.36 & 0.43 & 0.38 & 0.28 & 0.38 & 0.58 & 0.36 & $0.27 * *$ \\
\hline & \multicolumn{8}{|c|}{ 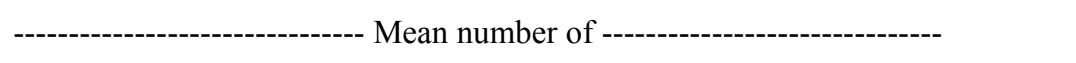 } \\
\hline Household members & 7.08 & 9.04 & 6.59 & $5.70 * * *$ & 11.06 & 17.50 & 10.24 & $7.71 * * *$ \\
\hline Hammer mills & 0.02 & 0.04 & 0.01 & 0.00 & 0.04 & 0.04 & 0.09 & 0.00 \\
\hline Hand mills & 0.02 & 0.04 & 0.01 & 0.01 & 0.17 & 0.42 & 0.15 & $0.03 * * *$ \\
\hline Bicycles & 0.43 & 0.62 & 0.51 & $0.19 * * *$ & 0,79 & 1.50 & 0.76 & $0.37 * * *$ \\
\hline Radios & 0.53 & 0.64 & 0.67 & $0.31 * *$ & 0.94 & 1.71 & 0.73 & $0.63 * * *$ \\
\hline Television (TV) sets & 0.07 & 0.13 & 0.07 & $0.00 * *$ & 0.17 & 0.54 & 0.09 & $0.00 * * *$ \\
\hline Ox-drawn implements & 0.72 & 1.07 & 0.77 & $0.36^{* * *}$ & 1.45 & 2.88 & 1.45 & $0.55^{* * *}$ \\
\hline \multicolumn{9}{|l|}{ Livestock } \\
\hline Cattle & 4.46 & 7.94 & 4.20 & $1.45^{* * *}$ & 26.96 & 80.75 & 16.24 & $2.29 * * *$ \\
\hline Oxen & 0.73 & 1.36 & 0.72 & $0.15^{* * *}$ & 2.15 & 5.52 & 1.84 & $0.32 * * *$ \\
\hline Sheep & 0.46 & 0.64 & 0.77 & 0.00 & 0.35 & 1.17 & 0.15 & $0.00 * *$ \\
\hline Goats & 2.81 & 4.30 & 2.46 & $1.73 * *$ & 3.39 & 5.46 & 4.21 & 1.37 \\
\hline Pigs & 0.20 & 0.35 & 0.25 & 0.03 & 1.25 & 2.46 & 0.73 & 0.95 \\
\hline Donkeys & 0.12 & 0.28 & 0.10 & $0.00 * *$ & 0.05 & 0.00 & 0.12 & 0.03 \\
\hline Poultry & 7.39 & 11.48 & 7.77 & $3.23 * * *$ & 23.60 & 50.79 & 19.21 & $10.24^{* * *}$ \\
\hline
\end{tabular}

Significance (based on ANOVA tests): $*=10 \% ; * *=5 \% ; * * *=1 \%$ 
Namwala, the non-hotspot district, has by far the largest livestock numbers with a median of 5.8 tropical livestock units (TLUs) per household, compared to 3.0 and 0.7 for Sinazongwe and Kazungula, respectively. Namwala also has the most skewed distribution of TLUs with a Gini coefficient of 0.91 , compared to 0.68 and 0.76 for Sinazongwe and Kazungula, respectively.

Within each district stratum (hotspot or non-hotspot), household characteristics and asset ownership are significantly better the more non-poor the household is. One-way analysis of variance (ANOVA) shows that these differences are statistically significant for most of the variables, regardless of the district. However, within each district stratum, household characteristics and asset ownership are significantly better the more non-poor the household is. In the hotspot districts, for example, poor households are significantly more likely to be female headed than their relatively less poor counterparts whereas in the non-hotspot district households are generally more likely to be male-headed regardless of their relative poverty status. On the other hand, the disparity in households' membership to social groups among wealth groups was significant only in the non-hotspot district.

Table 2 also shows that the magnitudes of the group differences are much more pronounced in the non-hotspot district than in the hotspot districts. This is not because the poor in the non-hotspot district are poorer but because the non-poor are significantly richer than their counterparts in the hotspot districts. This calls for caution in interpreting the food security classes and clearly identifies the need to appreciate the relative nature of the rankings.

\subsection{Econometric Results}

\subsubsection{All livestock}

Table 3 presents tier 1 and tier 2 tobit marginal effects for the basic model (Equation 5) in columns 1 and 2 and for the model with interactions (Equation 6) in models 3 and 4, taking TLUs per capita as the dependent variable.

The results show that 60 percent of the households in the study area own at least one of the various species of livestock. They also seem to suggest that livestock are more likely to be reared (and in larger numbers) in places where land is under communal tenure than places with borrowed and/or rented land. The results also confirm the importance of community productive potential, raising the likelihood of owning livestock by 9 percentage points in low market access areas. When high productive potential is combined with high market access, the likelihood of owning livestock increases more than five-fold while the effect on the mean number of livestock owned increases from 0.5 to 2.8 TLUs per capita.

However, these community productive potential and market access effects are virtually undone when the households in question are also regarded as food insecure or extremely food insecure. For example, the probability of owning livestock in a highly productive community with high market access reduces significantly by 46 percent when the household is regarded as being extremely food insecure. The average number of livestock per capita among owners also drops by 1.8 tropical livestock units. 
Table 3. Tobit marginal effects for livestock production in tropical livestock units

\begin{tabular}{|c|c|c|c|c|}
\hline \multirow[b]{2}{*}{ VARIABLES } & \multicolumn{2}{|c|}{ Basic model } & \multicolumn{2}{|c|}{ Model with interactions } \\
\hline & Tier 1 & Tier 2 & Tier 1 & Tier 2 \\
\hline & (1) & (2) & (3) & (4) \\
\hline \multirow[t]{2}{*}{ Sex of the household head, $1=$ male } & -0.0081 & -0.0413 & -0.0103 & -0.0508 \\
\hline & $(0.0340)$ & $(0.1755)$ & $(0.0323)$ & $(0.1618)$ \\
\hline \multirow[t]{2}{*}{ Communal land tenure, $1=$ yes (base=borrowed/rented) } & 0.1103 & 0.5621 & $0.1228 *$ & 0.6051 \\
\hline & $(0.0701)$ & $(0.3592)$ & $(0.0725)$ & $(0.3703)$ \\
\hline \multirow[t]{2}{*}{ Member of farmer group, $1=$ yes } & 0.0429 & 0.2185 & 0.0574 & 0.2828 \\
\hline & $(0.0438)$ & $(0.2508)$ & $(0.0452)$ & $(0.2558)$ \\
\hline \multicolumn{5}{|c|}{ Community type (1=yes; base = low productive potential, low market access) } \\
\hline \multirow[t]{2}{*}{ Low productive potential, high market access (comtype2) } & 0.0256 & 0.1302 & 0.0647 & 0.3191 \\
\hline & $(0.0251)$ & $(0.1313)$ & $(0.0405)$ & $(0.2008)$ \\
\hline \multirow[t]{2}{*}{ High productive potential, low market access (comtype3) } & $0.0798^{*}$ & 0.4065 & $0.0944 * *$ & $0.4651 * *$ \\
\hline & $(0.0466)$ & $(0.2576)$ & $(0.0437)$ & $(0.2221)$ \\
\hline \multirow[t]{2}{*}{ High productive potential, high market access (comtype4) } & $0.2540 * * *$ & $1.2940 * * *$ & $0.5580 * * *$ & $2.7507 * * *$ \\
\hline & $(0.0414)$ & $(0.3807)$ & $(0.1247)$ & $(1.0128)$ \\
\hline \multicolumn{5}{|l|}{ Household food security status (1=yes; base $=$ food secure) } \\
\hline \multirow[t]{2}{*}{ Food insecure (fscat2) } & -0.0762 & -0.3881 & 0.0380 & 0.1875 \\
\hline & $(0.0495)$ & $(0.2837)$ & $(0.0326)$ & $(0.1763)$ \\
\hline \multirow{2}{*}{ Extremely food insecure (fscat3) } & $-0.3003 * * *$ & $-1.5300 * * *$ & $-0.1356 * * *$ & $-0.6684 * * *$ \\
\hline & $(0.0309)$ & $(0.3515)$ & $(0.0466)$ & $(0.2190)$ \\
\hline \multicolumn{5}{|l|}{ Interaction terms } \\
\hline \multirow[t]{2}{*}{ comtype $2 *$ fscat 2} & & & $-0.1165 * *$ & $-0.5741 * *$ \\
\hline & & & $(0.0557)$ & $(0.2896)$ \\
\hline \multirow[t]{2}{*}{ comtype $2 *$ fscat 3} & & & -0.0685 & -0.3374 \\
\hline & & & $(0.0611)$ & $(0.3003)$ \\
\hline \multirow[t]{2}{*}{ comtype $3 *$ fscat 2} & & & -0.0212 & -0.1045 \\
\hline & & & $(0.1192)$ & $(0.5841)$ \\
\hline \multirow[t]{2}{*}{ comtype $3 *$ fscat 3} & & & -0.0588 & -0.2896 \\
\hline & & & $(0.0672)$ & $(0.3286)$ \\
\hline \multirow[t]{2}{*}{ comtype $4 *$ fscat 2} & & & $-0.3236^{*}$ & -1.5951 \\
\hline & & & $(0.1764)$ & $(1.0889)$ \\
\hline \multirow[t]{2}{*}{ comtype $4 *$ fscat 3} & & & $-0.5448 * * *$ & $-2.6853 * *$ \\
\hline & & & $(0.1338)$ & $(1.0445)$ \\
\hline \multicolumn{5}{|l|}{ District dummy variables (base $=$ Sinazongwe) } \\
\hline \multirow[t]{2}{*}{ Namwala, $1=y e s$} & $0.1160 * *$ & $0.5909 * *$ & $0.1016^{* *}$ & $0.5008 * *$ \\
\hline & $(0.0463)$ & $(0.2716)$ & $(0.0476)$ & $(0.2436)$ \\
\hline \multirow[t]{2}{*}{ Kazungula, $1=$ yes } & $-0.1367 * * *$ & $-0.6963 * * *$ & $-0.1652 * * *$ & $-0.8141 * * *$ \\
\hline & $(0.0354)$ & $(0.2457)$ & $(0.0363)$ & $(0.2671)$ \\
\hline Observations & 305 & 305 & 305 & 305 \\
\hline Left censored observations & 31 & 31 & 31 & 31 \\
\hline Predicted value & 0.597 & 3.711 & 0.590 & 3.653 \\
\hline F statistic & $2.71 * * *$ & $2.71 * * *$ & $2.84 * * *$ & $2.84 * * *$ \\
\hline
\end{tabular}

Robust standard errors in parentheses

$* * * \mathrm{p}<0.01, * * \mathrm{p}<0.05, * \mathrm{p}<0.1$

Dependent variable $=$ Tropical livestock units per capita 
The results in Table 3 also show, as expected, that, compared to Sinazongwe, livestock-owning households own significantly more TLUs per capita if they are located in Namwala and significantly less TLUs if in Kazungula. However, while the probability of owning livestock is significantly lower in Kazungula, the difference is positive and statistically significant between Sinazongwe and Namwala. Thus, all else being equal, Namwala households are more likely to own livestock than their counterparts in Sinazongwe. Another difference arises in the constituents and numbers of tropical livestock units. Namwala households are more likely to own larger livestock species like cattle, while Sinazongwe households are more likely to own smaller livestock species like goats.

\subsubsection{Livestock-specific models}

Table 4 presents the tobit marginal effects for the full livestock ownership model (with interactions) for each of three major livestock species - cattle, goats and poultry. Each livestock species has two columns of marginal effects, one for the first tier and the other for the second tier. We discuss the results for each species in the next sub-sub-subsections, starting with cattle.

\section{$\underline{\text { Cattle }}$}

The major results for cattle are quite similar to those for the combined TLU model. This could be because, in communities where cattle-rearing is dominant, it is expected that cattle will contribute the most to the computed TLU. Owing to the sheer size, cattle have by far the largest TLU conversion factors in these systems than any other livestock type. A couple of differences are, however, worth noting between the combined model and the cattle-only model. For example, although communal land tenure is associated with a higher likelihood of owning cattle, compared to alternative tenure systems in our data, the difference is not statistically significant. Just about 42 percent of the interviewed households in the three districts own cattle. Most of the cattle owners and cattle numbers are found in Namwala. An average individual in Namwala is 11 percent more likely to own cattle and to own about 0.5 more cattle than an average household in Sinazongwe. Kazungula is the least in terms of cattle ownership, with the residents being 19-20 percent less likely to own cattle and owning 0.9 animals less than Sinazongwe residents.

Unlike the combined model, cattle are more likely to be owned by people residing in high productive potential, high market access areas. People in high productive potential, high market access communities are as much as 37 percent more likely to own cattle and to own as much as 1.3 animals more than those who live in marginal areas. However, ownership is dominated by the richer members of these relatively more affluent communities. For example, individuals in extremely poor households are 23 percent less likely to own cattle than their non-poor neighbours. The result that cattle are owned by the wealthier holds true regardless of the district or community stratum.

\section{$\underline{\text { Goats }}$}

Columns 3 and 4 of Table 4 present marginal effects for the goats model. As expected goats are most prevalently reared in Sinazongwe than any of the other two districts. An average 


\section{Macrothink}

Research in Applied Economics

ISSN 1948-5433

2014, Vol. 6, No. 2

household in Kazungula and Namwala is 30 percent and 18 percent less likely to own goats, respectively, than a typical household in Sinazongwe. The numbers of goats are also significantly larger among Sinazongwe goat owners than they are among goat owners from the other two districts. While poverty has an unambiguously dampening effect on goat ownership, market access does not have a clear-cut effect. In fact, households in communities with high productive potential and high market access are significantly less likely to own goats than their counterparts in low-productive potential, low market access communities. The numbers among owners are also significantly larger in marginal areas than they are in more productive areas with greater market access.

Within the high productive potential areas with high market access, goats are also likely to be reared by poor households. Extremely poor households located in these areas are 27 percent more likely to own goats than their richer neighbours. Moreover, the goat-owning extremely poor households own 0.4 more goats than their richer goat-owning neighbors. Goats are also more likely to be reared on communal land than any other tenure systems captured in our data.

\section{Poultry}

Tier 1 and Tier 2 marginal effects for the poultry model are presented in columns 5 and 6 of Table 4, respectively. The results indicate that non-poor households in high potential communities with low market access have significantly greater probability of owning poultry and that the numbers of poultry owned per capita are significantly higher, compared to their counterparts in low-productive potential, low-market access communities. Thus, for the non-poor, poultry production does depend on the productive potential of the communities in which the households are located. Households in highly accessible areas are more likely to rear cattle and not goats or poultry. However, like other livestock types, the community effect is greatly reduced by poverty and food insecurity. 


\section{Macrothink}

Research in Applied Economics

ISSN 1948-5433

2014, Vol. 6, No. 2

Table 4. Tobit marginal effects for cattle, goats and poultry

\begin{tabular}{|c|c|c|c|c|c|c|}
\hline \multirow[b]{2}{*}{ VARIABLES } & \multicolumn{2}{|c|}{ Cattle } & \multicolumn{2}{|c|}{ Goats } & \multicolumn{2}{|c|}{ Poultry } \\
\hline & Tier 1 & Tier 2 & Tier 1 & Tier 2 & Tier 1 & Tier 2 \\
\hline & (1) & (2) & (3) & (4) & $(5)$ & $(6)$ \\
\hline Sex of the household head, $1=$ male & $\begin{array}{c}0.0172 \\
(0.0580)\end{array}$ & $\begin{array}{c}0.0623 \\
(0.2119)\end{array}$ & $\begin{array}{c}0.0379 \\
(0.0599)\end{array}$ & $\begin{array}{c}0.0628 \\
(0.0996)\end{array}$ & $\begin{array}{c}0.0627 \\
(0.0624)\end{array}$ & $\begin{array}{c}0.1969 \\
(0.1947)\end{array}$ \\
\hline $\begin{array}{l}\text { Communal land tenure, } 1=\text { yes } \\
\text { (base=borrowed/rented) }\end{array}$ & $\begin{array}{l}0.2056^{*} \\
(0.1189)\end{array}$ & $\begin{array}{l}0.7455 \\
(0.4771)\end{array}$ & $\begin{array}{l}0.2304 * \\
(0.1284)\end{array}$ & $\begin{array}{c}0.3813 \\
(0.2323)\end{array}$ & $\begin{array}{c}0.0466 \\
(0.1284)\end{array}$ & $\begin{array}{l}0.1462 \\
(0.4027)\end{array}$ \\
\hline Member of farmer group, $1=$ yes & $\begin{array}{c}0.0118 \\
(0.0417)\end{array}$ & $\begin{array}{c}0.0429 \\
(0.1490)\end{array}$ & $\begin{array}{l}-0.0063 \\
(0.0414)\end{array}$ & $\begin{array}{l}-0.0104 \\
(0.0689)\end{array}$ & $\begin{array}{c}0.0219 \\
(0.0388)\end{array}$ & $\begin{array}{c}0.0687 \\
(0.1220)\end{array}$ \\
\hline \multicolumn{7}{|c|}{ Community type (1=yes; base = low productive potential, low market access) } \\
\hline $\begin{array}{l}\text { Low productive potential, high } \\
\text { market access (comtype2) }\end{array}$ & $\begin{array}{c}0.0356 \\
(0.0552)\end{array}$ & $\begin{array}{c}0.1289 \\
(0.1979)\end{array}$ & $\begin{array}{c}0.0787 \\
(0.0738)\end{array}$ & $\begin{array}{c}0.1303 \\
(0.1221)\end{array}$ & $\begin{array}{c}0.0986 \\
(0.0639)\end{array}$ & $\begin{array}{c}0.3095 \\
(0.2040)\end{array}$ \\
\hline $\begin{array}{l}\text { High productive potential, low } \\
\text { market access (comtype } 3 \text { ) }\end{array}$ & $\begin{array}{c}0.0868 \\
(0.0653)\end{array}$ & $\begin{array}{c}0.3149 \\
(0.2411)\end{array}$ & $\begin{array}{l}0.1886^{*} \\
(0.1082)\end{array}$ & $\begin{array}{c}0.3121 \\
(0.1923)\end{array}$ & $\begin{array}{c}0.3661^{* * *} \\
(0.1108)\end{array}$ & $\begin{array}{c}1.1495^{* * *} \\
(0.3692)\end{array}$ \\
\hline $\begin{array}{l}\text { High productive potential, high } \\
\text { market access (comtype4) }\end{array}$ & $\begin{array}{c}0.3720^{* * *} \\
(0.1108)\end{array}$ & $\begin{array}{c}1.3486^{* * *} \\
(0.4228)\end{array}$ & $\begin{array}{l}-0.2882 * * * \\
(0.0861)\end{array}$ & $\begin{array}{c}-0.4770 * * * \\
(0.1567)\end{array}$ & $\begin{array}{c}0.0672 \\
(0.0660)\end{array}$ & $\begin{array}{c}0.2109 \\
(0.2082)\end{array}$ \\
\hline \multicolumn{7}{|c|}{ Household food security status $(1=$ yes; base $=$ food secure $)$} \\
\hline Food insecure (fscat2) & $\begin{array}{c}-0.0770^{*} \\
(0.0467)\end{array}$ & $\begin{array}{l}-0.2790 \\
(0.1745)\end{array}$ & $\begin{array}{l}-0.0574 \\
(0.0800)\end{array}$ & $\begin{array}{l}-0.0950 \\
(0.1331)\end{array}$ & $\begin{array}{c}0.0922 \\
(0.0591)\end{array}$ & $\begin{array}{c}0.2896 \\
(0.1870)\end{array}$ \\
\hline Extremely food insecure (fscat3) & $\begin{array}{c}-0.2294 * * * \\
(0.0779)\end{array}$ & $\begin{array}{c}-0.8317 * * * \\
(0.2989)\end{array}$ & $\begin{array}{c}-0.1826 * * \\
(0.0926)\end{array}$ & $\begin{array}{c}-0.3022^{*} \\
(0.1568)\end{array}$ & $\begin{array}{l}-0.1293 \\
(0.1027)\end{array}$ & $\begin{array}{l}-0.4061 \\
(0.3224)\end{array}$ \\
\hline \multicolumn{7}{|l|}{ Interaction terms } \\
\hline comtype $2 \mathrm{x}$ fscat 2 & $\begin{array}{l}-0.0702 \\
(0.0855)\end{array}$ & $\begin{array}{l}-0.2546 \\
(0.3069)\end{array}$ & $\begin{array}{c}0.0714 \\
(0.1239)\end{array}$ & $\begin{array}{c}0.1182 \\
(0.2079)\end{array}$ & $\begin{array}{l}-0.1707^{*} \\
(0.0982)\end{array}$ & $\begin{array}{c}-0.5361 * \\
(0.3107)\end{array}$ \\
\hline comtype $2 \mathrm{x}$ fscat 3 & $\begin{array}{l}-0.1654 \\
(0.1079)\end{array}$ & $\begin{array}{l}-0.5995 \\
(0.4041)\end{array}$ & $\begin{array}{l}-0.0712 \\
(0.1228)\end{array}$ & $\begin{array}{l}-0.1178 \\
(0.2047)\end{array}$ & $\begin{array}{c}0.0429 \\
(0.1254)\end{array}$ & $\begin{array}{c}0.1347 \\
(0.3942)\end{array}$ \\
\hline comtype $3 \mathrm{x}$ fscat 2 & $\begin{array}{c}0.0777 \\
(0.1337)\end{array}$ & $\begin{array}{c}0.2817 \\
(0.5123)\end{array}$ & $\begin{array}{c}0.0172 \\
(0.1626)\end{array}$ & $\begin{array}{c}0.0285 \\
(0.2700)\end{array}$ & $\begin{array}{l}-0.2573 \\
(0.1572)\end{array}$ & $\begin{array}{l}-0.8080 \\
(0.4966)\end{array}$ \\
\hline comtype $3 \mathrm{x}$ fscat 3 & $\begin{array}{c}-0.2035 \\
(0.1365)\end{array}$ & $\begin{array}{l}-0.7377 \\
(0.5126)\end{array}$ & $\begin{array}{l}-0.0011 \\
(0.1533)\end{array}$ & $\begin{array}{l}-0.0018 \\
(0.2538)\end{array}$ & $\begin{array}{c}-0.3068^{* *} \\
(0.1551)\end{array}$ & $\begin{array}{c}-0.9633^{*} \\
(0.5001)\end{array}$ \\
\hline comtype $4 \mathrm{x}$ fscat 2 & $\begin{array}{l}-0.0412 \\
(0.1529)\end{array}$ & $\begin{array}{l}-0.1494 \\
(0.5545)\end{array}$ & $\begin{array}{c}0.0426 \\
(0.1472)\end{array}$ & $\begin{array}{c}0.0705 \\
(0.2440)\end{array}$ & $\begin{array}{c}-0.1672 \\
(0.1021)\end{array}$ & $\begin{array}{l}-0.5249 \\
(0.3220)\end{array}$ \\
\hline comtype $4 \mathrm{x}$ fscat 3 & $\begin{array}{c}-0.3141^{* *} \\
(0.1411)\end{array}$ & $\begin{array}{c}-1.1387 * * \\
(0.5348)\end{array}$ & $\begin{array}{c}0.2676^{* *} \\
(0.1306)\end{array}$ & $\begin{array}{c}0.4428 * * \\
(0.2197)\end{array}$ & $\begin{array}{l}-0.0374 \\
(0.1294)\end{array}$ & $\begin{array}{l}-0.1175 \\
(0.4063)\end{array}$ \\
\hline \multicolumn{7}{|c|}{ District dummy variables $(1=$ yes; base $=$ Sinazongwe $)$} \\
\hline Namwala & $\begin{array}{l}0.1000^{*} \\
(0.0593)\end{array}$ & $\begin{array}{l}0.3627^{*} \\
(0.1943)\end{array}$ & $\begin{array}{c}-0.1750^{* * *} \\
(0.0556)\end{array}$ & $\begin{array}{c}-0.2896^{* * *} \\
(0.1077)\end{array}$ & $\begin{array}{c}0.2548^{* * *} \\
(0.0458)\end{array}$ & $\begin{array}{c}0.7999 * * * \\
(0.1570)\end{array}$ \\
\hline Kazungula & $\begin{array}{c}-0.2057^{* * *} \\
(0.0472) \\
\end{array}$ & $\begin{array}{c}-0.7458^{* * *} \\
(0.2471) \\
\end{array}$ & $\begin{array}{c}-0.2915^{* * *} \\
(0.0436)\end{array}$ & $\begin{array}{c}-0.4824 * * * \\
(0.1166) \\
\end{array}$ & $\begin{array}{c}0.1017^{* *} \\
(0.0475) \\
\end{array}$ & $\begin{array}{c}0.3195^{* *} \\
(0.1544)\end{array}$ \\
\hline Observations & 304 & 304 & 305 & 305 & 305 & 305 \\
\hline Left censored observations & 136 & 136 & 190 & 190 & 65 & 65 \\
\hline Predicted value & 0.423 & 3.234 & 0.338 & 1.163 & 0.702 & 2.046 \\
\hline F Statistic & $1.82^{* * *}$ & $1.82^{* * *}$ & $2.12^{* * *}$ & $2.12^{* * *}$ & $4.08^{* * *}$ & $4.08^{* * *}$ \\
\hline
\end{tabular}

Robust standard errors in parentheses

*** $\mathrm{p}<0.01,{ }^{* *} \mathrm{p}<0.05,{ }^{*} \mathrm{p}<0.1$

Dependent variable $=$ Livestock ownership per capita 
The spread of the poultry production activity across the three districts is also quite unique and different from the other two livestock species. Like cattle, Namwala households are not only more likely to engage in poultry production but they also rear larger numbers than their counterparts in Sinazongwe. However, unlike the other two livestock types, Kazungula households have more poultry and are more likely to rear poultry than Sinazongwe households.

\section{Summary and Conclusions}

This paper uses household data collected from livestock rearing communities in 3 districts in Southern Province of Zambia and censored regression models to measure the effect of productive potential and market access on livestock production. We also test for the existence of heterogeneous effects across agro-ecological regions, livestock species and poverty levels.

The results confirm that the largest tropical livestock units per capita are likely to be found in districts and communities with high productive potential and high market access. In our data, households in low potential districts like Kazungula and Sinazongwe districts own significantly lower numbers of livestock and assets than their counterparts in Namwala District. Namwala also has the most skewed distribution of assets and livestock. The results also suggest that livestock are most likely to be reared by non-poor households. Thus, one can conclude that the smallholder livestock enterprise in general responds to the communities' productive potential and market access, but only for the relatively non-poor households.

When disaggregated by livestock type, interesting differences emerge. While cattle rearing is greatly enhanced by both the productive potential and market accessibility of the communities, goats are mostly reared in marginal areas with low market accessibility. Poultry rearing occupies a middle ground as it is most prevalent in high -productive-potential, low market access communities. Thus, market access matters only for cattle, while productive potential is important for cattle and poultry but not goats. The spatial distribution of these livestock enterprises also differ from species to species. While cattle are most prevalent in Namwala, goats are most prevalent in Sinazongwe. Poultry, on the other hand, are more prevalent in Namwala and Kazungula than they are in Sinazongwe, with Namwala having the greatest likelihood of owning and numbers owned per capita. The results that goat ownership is greater in marginal districts and communities and that it is more prevalent among poorer households in high productive potential, high market access areas support the long-held conventional wisdom that goats are for the poor.

These findings clearly identify the need for policies and interventions that are aimed at strengthening livestock-based livelihood systems to be responsive to not only the target groups but also productive and market access characteristics of the communities in which they live. The livestock systems inherent in the various districts also need to be explicitly taken into account. 


\section{Acknowledgements}

This study is in part based on work done by the authors for the International Livestock Research Institute (ILRI) and the Food and Agriculture Organization of the United Nations (FAO). Jairos Sambo also provided invaluable research assistance support during the final stages of the manuscript. The authors would also like to thank most sincerely the Department of Veterinary Services staff (Headquarters and Southern Province staff) for their support during field work. We also thank the farmers that participated in the study, without whom the paper would not be possible. The views expressed in this paper do not necessarily represent the official positions of these organizations and/or individuals. All errors in interpretation are the authors' own.

\section{References}

Ali, A., \& Khan, M. A. (2013). Livestock ownership in ensuring Rural Household Food Security in Pakistan. The Journal of Animal and Plant Sciences, 23, 313-318.

Aregheore, E. M. (2006). Zambia II Country Pasture/Forage Resource Profiles. Ruminant Livestock Production Systems. Lusaka, Zambia.

Chapoto, A., Banda, D., Haggblade, P., \& Hamukwala, P. (2011). Factors Affecting Poverty Dynamics in Rural Zambia. FSRP working paper, Lusaka, Zambia.

Chilonda, P., Van Huylenbroeck, G., D’Haese, L., Musaba, E.C., Samui, K.L., \& Ahmadu, B. (2000). Small-scale cattle production in Eastern Province, Zambia: Objectives, Productivity and Constraints. Outlook on Agriculture, 29, 109-121. http://dx.doi.org/10.5367/000000000101293112

Cragg, J. (1971). Some statistical models for limited dependent variables with application to the demand for durable goods. Econometrica, 39, 829-844. http://dx.doi.org/10.2307/1909582

CSO. (2004). Living Conditions Monitoring Survey 2004. Central Statistical Office, Government of the Republic of Zambia, Lusaka, Zambia

CSO. (2010). Census of Population and Housing Report. Central Statistical Office, Government of the Republic of Zambia. Lusaka, Zambia

Daka, D. E. (2002). Livestock sector in Zambia: Opportunities and limitations. In IAEA (International Atomic Energy Agency) (Eds). Development and Field Evaluation of Animal Feed Supplementation Packages: Proceedings of the Final review Meeting held in Cairo, Egypt 25-29, November 2000. Vienna, Austria: IAEA. URL (last checked 12 January 2014) http://www-naweb.iaea.org/nafa/aph/public/reports-12.pdf

Deshingkar, P., Farrington, J., Rao, L., Akter, S., Sharma, P., Freeman, A., \& Reddy, J. (2008). Livestock and Poverty Reduction in India: Findings from ODI livelihood Options Project. Discussion Paper \# 8. ILRI, Addis Abba, Ethiopia. 
DVLD. (2007). Annual Report. Ministry of Agriculture and Cooperatives. Lusaka, Zambia.

Gujarati, D. (2003). Basic Econometrics. (4th ed.). Boston, MA: McGraw-Hill Higher Education.

Janke, H. F. (1982). Livestock production systems and livestock development in tropical Africa. Kiel, Germany.

Langyintuo, A.S., Hamazakaza, P., Nawale, E., \& Jere, I. (2005). Maize Production in Zambia: Setting Indicators for Impact Assessment and Targeting. CIMMYT, Strengthening Seed Marketing Incentives in Southern Africa to Increase the Impact of Maize Breeding Research Project.

Lin, T., \& Schmidt P. (1984). A test of the tobit specification against an alternative suggested by Cragg. Review of Economics and Statistics, 66, 174-177. http://dx.doi.org/10.2307/1924712

Lubungu, M., \& Mukuka, R. M. (December 2012). Status of the Smallholder Livestock Sector in Zambia: Submitted to the Parliamentary Committee on Agriculture and Land. Technical Paper Number 1, Indaba Agricultural Policy Research Institute, Lusaka, Zambia.

Lubungu, M., Chapoto, A., \& Tembo, G. (August 2012). Smallholder Farmer Participation in Livestock Markets: The Case for Zambian Farmers. Working Paper Number 66, Indaba Agricultural Policy Research Institute, Lusaka, Zambia.

Makhura, M. T. (2001). Overcoming Transaction Costs Barriers to Market Participation of Smallholder Farmers in the Northern Province of South Africa. Master's Thesis

Mandleni, B., \& Anim, F. D. K. (2012). Climate Change and Adaptation of Small-Scale Cattle and Sheep Farmers. African Journal of Agricultural Research, 7, 2639-2645. http://dx.doi.org/10.5897/AJAR10.747

McDonald, J., \& Moffit, R. (1980). The Use of Tobit Analysis. Review of Economics and Statistics, 62, 318-321. http://dx.doi.org/10.2307/1924766

Brian, P. M., Richardson, R. B., Tembo, G., \& Mapemba, L. 2014. Rural Household Participation in Markets for Non-Timber Forest Products in Zambia. Environment and Development Economics, 19(1), 1-18, Available on CJO 2013 http://dx.doi.org/10.1017/S1355770X13000569

Negassa, A., \& Jabber, M. (2008). Livestock Ownership, Commercial Off Take Rates and their Determinants in Ethiopia. Addis Ababa, Ethiopia.

Randolph, T. F., Schelling, E., Grace, D., Nicholson, C.F., Leroy, J.L., Cole, D. C., Demment, M. W., Omore, A., Zinsstag, J., \& Ruel, M. (2007). Invited Review: Role of livestock in human nutrition and health for poverty reduction in developing countries.

Rooyen, A., \& Tui, S. H. (2009). Promoting Goat Markets and Technology Development in Semi-Arid Zimbabwe for Food Security and Income Growth. Tropical and Subtropical 
Agro-ecosystems, 11, 1-5.

Simbaya, J. (2002). Availability and feeding quality characterstics of on farm produced feed resources in the traditional smallholder sector in Zambia. In IAEA (International Atomic Energy Agency) (Eds). Development and Field Evaluation of Animal Feed Supplementation Packages: Proceedings of the Final review Meeting held in Cairo, Egypt 25-29, November 2000. Vienna, Austria: IAEA. URL (last checked 12 January 2014) South-Western College Publishing.

Stroebel, A., Swanepoel, F. J. C., Nthakheni, N. D., Nesamvuni, A. E., \& Taylor, G. (2008). Benefits obtained from cattle by smallholder farmers: a case study of Limpopo Province, South Africa. Australian Journal of Experimental Agriculture, 48, 825-828. http://dx.doi.org/10.1071/EA08058

Tobin, J. (1958). Estimation of Relationships for Limited Dependent Variables. Econometrica, 26, 24-36. http://dx.doi.org/10.2307/1907382

Wooldridge, J.M. (2009). Introductory Econometrics: A Modern Approach (4e Edition). Mason, OH: South-Western Cengage Learning.

\section{Note}

Note 1. A Tropical Livestock Unit (TLU) is an animal unit that represents an animal of 250 $\mathrm{kg}$ live weight, and used to aggregate different species and classes of livestock as follows: Bullock :1.25; cattle: 1.0; goat, sheep and pig: 0.1; guinea fowl, chicken and duck: 0.04 and turkey: 0.05 (compiled after Janke 1982; and Langyintuo et al 2005).

\section{Copyright Disclaimer}

Copyright reserved by the author(s).

This article is an open-access article distributed under the terms and conditions of the Creative Commons Attribution license (http://creativecommons.org/licenses/by/3.0/). 